\title{
Hemşirelerin organ bağışına bakışları
}

\section{Perspective on organ donation for nurses}

\section{Elçin Balcı*, Mehtap Şahingöz}

Halk Sağlığı Anabilim Dalı (Doç. Dr. E. Balcı), Erciyes Üniversitesi Tıp Fakültesi, TR-38039 Kayseri, Sağlık Hizmetleri (Dr. M. Şahingöz), Niğde Üniversitesi Zübeyde Hanım Sağlık Hizmetleri Meslek Yüksekokulu, TR-51240 Niğde

\begin{abstract}
Özet
Amaç. Bu çalışmada Sivas il merkezinde görev yapan hemşirelerin, organ bağışı konusuna genel yaklaşımları, bilgi, tutum ve davranışlarının belirlenmesi amaçlanmıştır. Yöntem. Çalışmaya 750 hemşirenin katılması planlanmış ancak 641 hemşirenin katılımı ile tamamlanmıştır (Ulaşma oranı \%85,5). Tanımlayıcı ve kesitsel bir araştırmadır. Çalışmada, veriler bir anket formu ile toplanmış, yüzdelikler belirtilmiş ve analizlerde ki-kare testi kullanılmıştır. Bulgular. Araştırmaya katılan 641 hemşirenin yaş ortalaması 29,2 \pm 4,9 yıl idi. Hemşirelerin 95,3'ü kadın, \%40,2'si 26-30 yaşları arasında olup \%68,2'si lisans mezunuydu. Hemşirelerin \%98,1'i organ bağışında bulunmadığını ve $\% 53,5$ 'i de konu hakkında yeterli bilgisi olmadığını ifade etti. Hemşirelerin $\% 88,8$ 'i aileden birine organ gerekirse, \%18,4'i de hasta olan bir yabancıya organ gerekirse organlarını verebileceğini belirtti. Hemşirelerin \%31,0’i kişi organ bağışı yaptığı halde ölümünden sonra ailesinin itiraz etmeye hakkı olmadığını, \%2,3’ü ise organ bağışının ücretli bir işlem olduğunu düşünmekteydi. Hemşirelere organ bağışının nerelere yapılabileceği sorulduğunda \%87,4’ü organ bağış merkezleri yanıtını verdi. Bağışı mümkün olan organlar sorulduğunda hemşirelerin \%98,1'i böbrek yanıtını verdi. Ölmüş kimseler adına organ bağışı kararını birinci derece yakınlarının vereceğini düşünen hemşireler \%88,0’lık bir grubu oluşturdu. Organ bağışının artırılması için din görevlilerinden yardım alınması gerektiğini ifade edenlerin oranı \% 75,2 idi. Hemşirelerin \%1,9'u organ bağışı yaptığını ifade etti. Cinsiyete göre organ bağışı yapma durumu değerlendirildiğinde; kadınların \%1,6'sı, erkeklerin \%6,7'si organ bağışı yapmıştı ve gruplar arasındaki fark istatistiksel olarak anlamlıydı $(\mathrm{p}<0,05)$. Dini açıdan organ bağışının uygun olduğunu düşünenlerde organ bağışlama oranı daha yüksekti $(p<0,05)$. Sonuç. Sağlık profesyoneli olmaları nedeniyle daha bilgili ve hassas olmaları beklenen hemşirelerde organ bağışı konusunda bilgi eksiklikleri mevcuttur.
\end{abstract}

Anahtar sözcükler: Hemşire, organ, organ bağış1

\begin{abstract}
Aim. In this study it was aimed to determine the general approach,attitude,behaviour and knowledge of the nurses working in Sivas city center on donating organs. Methods. 750 nurses were planned to take part in this study; however, it was completed with the participating of 641 nurses (Access ratio:85\%). It is descriptive and cross-sectional study. The data were collected by a questionnaire and the percentages were specified and analyzed by chi-square test. Results. The mean age of the 641 nurses participated in the study was $29.2 \pm 4.9$ years. 95.3 percent of the nurses were female, $40.2 \%$ were between 26-30 years old and $68.2 \%$ had a bachelor's degree. $98.1 \%$ of the nurses stated that they had never donated any organs and $53.5 \%$ also stated that they hadn't had sufficient information on the subject. $88.8 \%$ of the nurses stated that they could give necessary organs to one family member, and $18.4 \%$ point out that they could donate necessary organs to a stranger patient if needed. $31.0 \%$ of the nurses thought that their families didn't have a right to appeal after their death when they had donated their organs and $2.3 \%$ thought that the process of organ donation was paid. When asked where organ donation may be made, $87.4 \%$ of the nurses responded organ donation centers. When asked about the organs which were possible to donate and $98.1 \%$ of nurses replied that it was kidney The nurses who thought that the first-degree relatives should give the decision of organ donation on the behalf of deceased person were $88.0 \%$. The rate of the nurses who stated that help should be recieved from the religious officials to increase organ donation was $75.2 \%, 1.9 \%$ of the nurses stated that they had donated organs. When the organ donation status were evaluated by sex; $1.6 \%$ of female and $6.7 \%$ of male had made organ donation and the difference between the goups was significant. The organ donation rate was
\end{abstract}


much higher among those who considered organ donation was suitable in religious aspects $(\mathrm{p}<0.05)$. Conclusion. Nurses who are expected to be accurate and more knowledgeable as they are health professionals lack of knowledge about organ donation.

Keywords: Nurse, organ, organ donation

Geliş tarihi/Received: 13 Ağustos 2014; Kabul tarihi/Accepted: 12 Aralık 2014

\author{
*İletişim adresi: \\ Dr. Elçin Balcı, Halk Sağlı̆̆ı Anabilim Dalı, Erciyes Üniversitesi Tıp Fakültesi, TR-38039 \\ Kayseri. E-posta: drelcin71@gmail.com
}

*Bu araştırma; Erciyes Üniversitesi’nden Etik Kurul izni, Sivas İl İdaresi’nden idari izin alınarak yapılmıștır.

\title{
Giriş
}

Organ bağışı; kişi hayatta iken serbest iradesi ile tıbben yaşamı sona erdikten sonra doku ve organlarının başka hastaların tedavisi için kullanılmasına izin vermesi ve bunu belgelendirmesidir. Tanımdan da anlaşılacağı üzere organ bağışı, hem canlı vericiler tarafından organlardan birinin ya da bir parçasının bağışlanmasını hem de ölümden sonraki bir uygulamayı yani kadavradan yapılabilecek organ bağışını kapsamaktadır [1]. $\mathrm{Bu}$ işlem, günümüzde birçok kronik organ hastalıklarında uygulanan rutin, geçerli ve ileri bir tedavi yöntemi olarak kabul görmektedir [2].

Günümüzde yeni doğmuştan 60 yaşa kadar olan ölülerden organ alınabildiği gibi, 18 veya üstünde bir yaşta olup akli dengesi yerinde olan herkes organ bağışında bulunabilir [3].

Ülkemizde yeterli sayıda organ ve doku nakli merkezi ve bu konuda deneyimli bilim adamları olduğu halde, başkasından alacağı organla hayata dönmesi ve sağlıklı bir hayat sürmesi mümkün olacak pek çok hasta insan organ beklemektedir. $\mathrm{Bu}$ hastalar ya dini gerekçelerle ya da konu hakkındaki yanlış bilgi ve inanışlar sebebiyle organ bulamamakta, tedavi olamamakta, gün geçtikçe sağlıklarını kaybetmekte ve hatta ölmektedirler [4].

Organ bağışlarını arttırabilmek için halkın yetersiz bilgisini, reddedici tavır ve tutumunu gidermek, tüm alanlarda bu konuyla ilgili engelleri aşmak gerekmektedir. Bunun için öncelikle sağlık profesyonellerinin bu konuda bilgi sahibi olmaları ve halk1 aydınlatmaları gerekmektedir. Hemşireler de hasta ve yakınlarıyla yakın iletişimi olan bir grup olarak bu konuda mesafe kat etmede rol alacak önemli bir yere sahiptir.

$\mathrm{Bu}$ araştırmada Sivas il merkezinde görev yapan hemşirelerin, organ bağışı konusuna genel yaklaşımları, bilgi, tutum ve davranışlarının belirlenmesi amaçlanmıştır.

\section{Gereç ve yöntem}

Tanımlayıcı ve kesitsel tipteki bu çalışma Sivas il merkezindeki birinci, ikinci, üçüncü basamak sağlık kuruluşları ve özel sağlık kuruluşlarında görev yapan hemşirelerde yapıldı. Araştırmada çalışma evreninin tümüne ulaşılması hedeflendiğinden örneklem seçilmedi. Kayıtlara göre görev yapan toplam 750 hemşireden çalışmaya katılmayı kabul etmeyenler ( 65 kişi) ve iki kere yerinde ziyaret edildiği halde kendilerine rapor, tayin, izin nedeniyle ulaşılamayan (44 kişi) çalışma dışında kaldı. Araştırma 641 hemşireye ulaşılarak tamamlandı (ulaşma oranı \% 85,5 ).

Veriler literatür işığında hazırlanan bir anket formuyla toplandı. Anket formu; hemşirelerin yaş, cinsiyet, eğitim durumu, medeni durum, çalıştığı bölüm, meslekte çalışma süresi ile ilgili 14 soru, organ bağışı ile ilgili 20 soru olmak üzere toplam 34 sorudan oluşmaktaydı. Anket formu, hemşireler çalıştıkları birimlerde ziyaret edilerek, gerekli açıklamalar yapılarak, çalışmayı kabul eden hemşirelerin kendileri tarafindan gözlem altında dolduruldu. Anket formu ile elde edilen veriler bilgisayar ortamında SPSS 
16,0 programı kullanılarak değerlendirildi. Değerlendirmede sayı ve yüzdelikler birlikte gösterildi ve analizde ki kare testi kullanıldı. $\mathrm{P}<0,05$ değerleri anlamlı kabul edildi.

Hemşirelerin görev yaptığı merkezler 1.basamak (Aile Sağlığı Merkezi-ASM ve Toplum Sağlığı Merkezi-TSM), 2. basamak (Numune Hastanesi, Devlet Hastanesi, Özel Hastane ve özel diyaliz merkezleri) ve 3 . basamak (Üniversite Hastanesi) olarak gruplandırıldı.

\section{Bulgular}

Araştırmaya katılan 641 hemşirenin yaş ortalaması 29,2 $\pm 4,9$ (min: 21; max: 62) yıl idi. Hemşirelerin 95,3'ü kadın, \%40,2'si 26-30 yaşları arasında olup \%68,2'si lisans mezunuydu. Hemşirelerin \%61,8'i evliydi ve \%50,4'ünün en az bir çocuğu vardı. Grubun \%55,5'i ikinci basamak sağlık kurumlarında çalışmaktaydı. Hemşirelerin \%73,8'inin vardiyalı çalıştığ 1 ve \%82,7'sinin haftalık ortalama çalışma süresinin 41 saat ve üstü olduğu tespit edildi (Tablo 1).

Tablo 1. Araştırma grubundaki hemşirelerin demografik ve bazı mesleki özellikleri.

\begin{tabular}{|c|c|c|}
\hline Sosyodemografik ve mesleki özellikler $(n=641)$ & Sayı & $\%$ \\
\hline \multicolumn{3}{|l|}{ Cinsiyet } \\
\hline Erkek & 30 & 4,7 \\
\hline Kadın & 611 & 95,3 \\
\hline \multicolumn{3}{|l|}{ Yaş grupları } \\
\hline 30 yaş ve altı & 419 & 65,4 \\
\hline 31 yaş ve üstü & 222 & 34,6 \\
\hline \multicolumn{3}{|l|}{ Öğrenim durumu } \\
\hline Lise & 47 & 7,3 \\
\hline Ön lisans & 150 & 23,4 \\
\hline Lisans & 437 & 68,2 \\
\hline Lisansüstü & 7 & 1,1 \\
\hline \multicolumn{3}{|l|}{ Medeni durum } \\
\hline Bekâr & 245 & 38,2 \\
\hline Evli & 396 & 61,8 \\
\hline \multicolumn{3}{|l|}{ Çocuğu } \\
\hline Olan & 323 & 50,4 \\
\hline Olmayan & 318 & 49,6 \\
\hline \multicolumn{3}{|l|}{ Çalıştığı kurum } \\
\hline Birinci basamak* & 37 & 5,8 \\
\hline İkinci basamak** & 356 & 55,5 \\
\hline Üçüncü basamak*** & 248 & 38,7 \\
\hline \multicolumn{3}{|l|}{ Meslekte toplam çalışma süresi } \\
\hline $0-12$ ay & 44 & 6,9 \\
\hline $13-60$ ay & 285 & 44,5 \\
\hline $61-120$ ay & 128 & 20,0 \\
\hline 121 ve üstü ay & 184 & 28,7 \\
\hline \multicolumn{3}{|l|}{ Halen bulunduğu sağlık kuruluşunda çalışma süresi } \\
\hline $0-12$ ay & 149 & 23,2 \\
\hline $13-60$ ay & 280 & 43,7 \\
\hline $61-120$ ay & 135 & 21,1 \\
\hline 121 ve üstü ay & 77 & 12,0 \\
\hline \multicolumn{3}{|l|}{ Çalışma şekli } \\
\hline Gündüz & 100 & 15,6 \\
\hline Vardiya & 473 & 73,8 \\
\hline Sorumlu hemşire & 68 & 10,6 \\
\hline \multicolumn{3}{|l|}{ Haftalık ortalama çalışma süresi } \\
\hline 40 saat ve alt 1 & 111 & 17,3 \\
\hline 41 saat ve üstü & 530 & 82,7 \\
\hline \multicolumn{3}{|c|}{$\begin{array}{l}\text { *1. basamak (ASM-TSM), **2. basamak (numune hastanesi, devle } \\
\text { hastanesi, özel hastane ve özel diyaliz merkezleri), ***3. basamal } \\
\text { (üniversite hastanesi) }\end{array}$} \\
\hline
\end{tabular}

Hemşirelerin \%98,1'i organ bağışında bulunmamıştı ve \%53,5'i konu hakkında yeterli bilgisi olmadığını ifade etti. Grubun \%99,2'sine göre organ bağışı yasaldı, \%50,5'ine göre dinen sakıncası yoktu. Aileden birine organ gerekirse $\% 88,8$ 'i, hasta olan kişi bir 
yabancı ise \%18,4'i organlarını verebileceğini belirtti. Grubun \%15,1'i kan bağışını organ bağışı olarak nitelerken, \%72,2'si hiç kan bağışında da bulunmamıştı. Türkiye'de organ bağışının yetersiz olduğunu düşünenler \%74,1 düzeyinde idi. Organların alınması için beyin ölümünün gerçekleşmesinin gerekli olduğunu ifade edenler \%91,4'lük bir grubu oluşturmaktaydı. Katılımcıların \%31,0'i kişi organ bağışı yaptığı halde ölümünden sonra ailesinin itiraz etmeye hakkı olmadığını, \%2,3'ü ise organ bağışının ücretli bir işlem olduğunu düşünmekteydi (Tablo 2).

Tablo 2. Katılımcıların organ bağışı ile ilgili görüş ve davranışlarına göre dağılımı.

\begin{tabular}{|c|c|c|}
\hline Organ bağıșı ile ilgili görüş ve davranışlar $(n=641)$ & Sayı & $\%$ \\
\hline \multicolumn{3}{|l|}{ Sizce organ bağıșı hakkındaki bilginiz yeterli midir? } \\
\hline Evet yeterli & 298 & 46,5 \\
\hline Hayır yetersiz & 343 & 53,5 \\
\hline \multicolumn{3}{|l|}{ Organ bağıșı yaptınız mı? } \\
\hline Evet & 12 & 1,9 \\
\hline Hayır & 629 & 98,1 \\
\hline \multicolumn{3}{|l|}{ Organ bağışı ücretli midir? } \\
\hline Organ bağışı ücretsizdir & 496 & 77,4 \\
\hline Organ bağışı ücretlidir & 15 & 2,3 \\
\hline Bilmiyorum & 130 & 20,3 \\
\hline \multicolumn{3}{|l|}{ Organ bağışının yasal boyutu nedir? } \\
\hline Organ bağışı yasaldır & 636 & 99,2 \\
\hline Organ bağışı yasal değildir & 5 & 0,8 \\
\hline \multicolumn{3}{|l|}{ Organ bağışının dini boyutu nedir? } \\
\hline Dinen sakıncas1 yoktur & 324 & 50,5 \\
\hline Dinen yanlıştır & 10 & 1,6 \\
\hline Bilmiyorum & 307 & 47,9 \\
\hline \multicolumn{3}{|c|}{ Ailenizden birine organ bağışı gerekse organ verir misiniz? } \\
\hline Veririm & 569 & 88,8 \\
\hline Vermem & 8 & 1,2 \\
\hline Kararsızım & 64 & 10,0 \\
\hline \multicolumn{3}{|c|}{ Tanımadığınız yabancı bir hastaya organ bağıșı gerekse organ verir misiniz? } \\
\hline Veririm & 118 & 18,4 \\
\hline Vermem & 168 & 26,2 \\
\hline Kararsizım & 355 & 55,4 \\
\hline \multicolumn{3}{|l|}{ Kan bağışı sizce organ bağışı sayılır mı? } \\
\hline Organ bağışı sayılır & 97 & 15,1 \\
\hline Organ bağışı değildir & 383 & 59,8 \\
\hline Karasızım & 161 & 25,1 \\
\hline \multicolumn{3}{|l|}{ Bugüne kadar hiç kan bağışında bulundunuz mu? } \\
\hline Evet bulundum & 178 & 27,8 \\
\hline Hayır bulunmadım & 463 & 72,2 \\
\hline \multicolumn{3}{|l|}{ Türkiye'de organ bağışı düzeyi sizce yeterli mi? } \\
\hline Bilmiyorum & 145 & 22,6 \\
\hline Yeterli & 21 & 3,3 \\
\hline Yetersiz & 475 & 74,1 \\
\hline \multicolumn{3}{|c|}{ Kişi ölmeden önce organ bağışı yapmışken öldükten sonra ailesi buna engel olabilir mi? } \\
\hline Olabilir hakları vardır & 299 & 46,6 \\
\hline Olamaz, kişi karar verip bağışı zaten yapmıştır & 199 & 31,0 \\
\hline Bilmiyorum & 143 & 22,3 \\
\hline \multicolumn{3}{|l|}{ Organlar ne zaman alınabilir? } \\
\hline Beyin ölümünün gerçekleşmesi gerekir & 586 & 91,4 \\
\hline Kalbin durmas1 gerekir & 46 & 7,2 \\
\hline Solunumun durması gerekir & 9 & 1,4 \\
\hline Toplam & 641 & 100,0 \\
\hline
\end{tabular}

Çalışma grubuna organ bağışı konusunda bilgileri ve bilgi kaynaklarının sorgulandığı sorular yöneltildi. Organ bağışının nerelere yapılabileceği sorulduğunda en yüksek düzeyde $(\% 87,4)$ organ bağış merkezleri ifade edildi. Bağış için gereken formaliteleri grubun \%28,1'i bilmiyorum diyerek yanıtsız bıraktı. Bağışı mümkün olan organlardan en fazla bilineni böbrek $(\% 98,1)$ idi. Ölmüş kimseler adına organ bağışı kararını birinci derece yakınlarının vereceğini düşünenler \%88,0'lik bir grubu oluşturdu. Organ bağışı 
yapabilecek/yapamayacak kişiler sorulduğunda grubun tamamı AIDS'li hastanın organ veremeyeceğini ifade ederken \%1,1'lik bir grup bulaşıcı hastalığı olanların verebileceğini belirtti. Organ bağışı konusundaki bilgilenme kaynaklarının başında internet $(\% 43,1)$ belirtildi. Organ bağışının artırılması için önerileri sorulduğunda; eğitimlerin artırılması $(\% 93,3)$, din görevlilerinden yardım alma $(\% 75,2)$, bağış yapanlara veya ailelerine ücret ödenmesi $(\% 53,2)$ ve kimsesiz cenazelerin izne gerek olmadan kullanılabilmesi $(\% 14,7)$ ilk siralarda dile getirildi (Tablo 3).

Tablo 3. Katılımcıların organ bağışı konusunda bilgileri ve bilgi kaynakları.

\begin{tabular}{|c|c|c|}
\hline \multirow[t]{2}{*}{ Organ bağışı konusunda $(n=641)$} & \multicolumn{2}{|c|}{ İșaretleyenler } \\
\hline & Sayı & $\%$ \\
\hline \multicolumn{3}{|l|}{ Bağış yapılabilecek birimler } \\
\hline Organ bağışı merkezine & 560 & 87,4 \\
\hline Üniversite hastanesine & 328 & 51,2 \\
\hline Devlet hastanesine & 256 & 39,9 \\
\hline İl sağlık müdürlüğüne & 200 & 31,2 \\
\hline Aile sağlı̆̆ı merkezine & 68 & 10,6 \\
\hline Sağlık ocağına & 57 & 8,9 \\
\hline Özel polikliniğe & 25 & 3,9 \\
\hline Bilmiyorum & 58 & 9,0 \\
\hline \multicolumn{3}{|l|}{ Organ bağışı yapmak için gerekli formaliteler gereklidir? } \\
\hline Nüfus cüzdanı & 403 & 62,9 \\
\hline Sağlık raporu & 306 & 47,7 \\
\hline Doktor izin belgesi & 163 & 25,4 \\
\hline Yakın akraba izin kağıdı & 46 & 7,2 \\
\hline Bilmiyorum & 180 & 28,1 \\
\hline \multicolumn{3}{|l|}{ Hangi organların bağıșı mümkündür? } \\
\hline Böbrek & 629 & 98,1 \\
\hline Kornea & 581 & 90,6 \\
\hline Kalp & 576 & 89,9 \\
\hline Kalp kapağ & 460 & 71,8 \\
\hline Akciğer & 295 & 46,0 \\
\hline Pankreas & 153 & 23,9 \\
\hline Mide-barsak & 47 & 7,3 \\
\hline Bilmiyorum & 14 & 2,2 \\
\hline \multicolumn{3}{|l|}{ Ölmüş kimselerin organlarını bağışlama kararını kim verebilir? } \\
\hline Birinci derece akrabaları & 564 & 88,0 \\
\hline Doktoru & 191 & 29,8 \\
\hline Bilmiyorum & 75 & 11,7 \\
\hline \multicolumn{3}{|l|}{ Kimler organ bağışı yapabilir? } \\
\hline Beyin ölümü gerçekleşenler & 623 & 97,2 \\
\hline Sağlıklı birey & 614 & 95,8 \\
\hline İntihar eden kişiler & 387 & 60,4 \\
\hline Tansiyon hastaları & 386 & 60,2 \\
\hline Tedavisi mümkün olmayan ilerleyici hastalığı olanlar & 374 & 58,3 \\
\hline Şeker hastaları & 281 & 43,8 \\
\hline Kanser hastası & 249 & 38,8 \\
\hline 18 yaşın altındaki bireyler & 88 & 13,7 \\
\hline Akli dengesi yerinde olmayanlar & 73 & 11,4 \\
\hline Bulaşıcı hastalığı olanlar & 7 & 1,1 \\
\hline AIDS hastası olanlar & - & - \\
\hline \multicolumn{3}{|l|}{ Organ bağışı konusunda bilgileri nereden edindiniz? } \\
\hline İnternetten & 276 & 43,1 \\
\hline Tv'den & 250 & 39,0 \\
\hline Çevreden & 243 & 37,9 \\
\hline Okuldan & 219 & 34,2 \\
\hline Hizmet içi eğitimden & 152 & 23,7 \\
\hline Ailemden & 4 & 0,6 \\
\hline \multicolumn{3}{|l|}{ Organ bağışını artırmak için neler yapılabilir? } \\
\hline Ĕgitimler artırılabilir & 598 & 93,3 \\
\hline Din görevlilerinden yardım istenebilir & 482 & 75,2 \\
\hline Organ bağışlayanlara ve/veya ailelerine ücret ödenebilir & 341 & 53,2 \\
\hline Kimsesiz tüm cenazelerin organları izne gerek olmadan alınabilir & 94 & 14,7 \\
\hline
\end{tabular}


Grubun \%1,9'u (12 kişi) organ bağışı yaptığını ifade etti. Cinsiyete göre organ bağışı yapma durumu değerlendirildiğinde; kadınların \%1,6's1, erkeklerin \%6,7'si organ bağışı yapmışı ve gruplar arasındaki fark istatistiksel olarak anlamlıydı $\left(X^{2}=3,938 ; p<0,05\right)$ (Tablo 4).

Tablo 4. Katılımeıların organ ve kan bağışı ile ilgili davranışlarının cinsiyetle iliş̧isi.

\begin{tabular}{lllllllll}
\hline & \multicolumn{7}{c}{ Kadın $(\mathbf{n = 6 1 1})$} & \multicolumn{2}{c}{ Erkek $(\mathbf{n = 3 0})$} & Toplam $(\mathbf{n = 6 4 1})$ & $\mathbf{X}^{\mathbf{2}}$ & \multirow{2}{*}{$\mathbf{p}$} \\
\cline { 2 - 8 } & Sayı & $\mathbf{\%}$ & Sayı & $\mathbf{\%}$ & Sayı & $\mathbf{\%}$ & & \\
\hline Organ bağışı yapanlar & 10 & 1,6 & 2 & 6,7 & 12 & 1,9 & 3,938 & 0,047 \\
Kan bağışı yapanlar & 163 & 26,7 & 15 & 50,0 & 178 & 27,8 & 7,755 & 0,005 \\
\hline
\end{tabular}

Grubun \%27,8'i (178 kişi) kan bağışı yaptığını ifade etti. Kadınların \%26,7'si, erkeklerin \%50,0'si kan bağışı yapmıştı ve gruplar arasındaki fark cinsiyet açısından istatistiksel olarak anlamliydı $\left(\mathrm{X}^{2}=7,755 ; \mathrm{p}<0,05\right)$.

Grubun \%50,5'i (324 kişi) organ bağışını dini açıdan doğru bulduğunu ifade etti. Kat1lımcılardan bilgim yeterli diyenlerin \%57,7'sine, bilgim yetersiz diyenlerin \%44,3'üne göre dini açıdan organ bağışı doğruydu ve gruplar arasındaki fark istatistiksel olarak anlamlıd $1\left(X^{2}=11,896 ; p<0,05\right)$ (Tablo 5).

Grubun \%26,2'si (168 kişi) tanımadığı bir kişiye organ vermeyeceğini ifade etti. Kat1lımcılardan bilgim yeterli diyenlerin \%13,4'ü, bilgim yetersiz diyenlerin $\% 31,8$ 'ü tanımadığı kişilere organ vermeyeceğini belirtti ve gruplar arasındaki fark istatistiksel olarak anlamlıydı $\left(X^{2}=18,785 ; \mathrm{p}<0,05\right)$ (Tablo 5).

Grubun \%3,3 (21 kişi) Türkiye'de organ bağış1 oranlarını yeterli bulduğunu ifade etti. Kat1lımcılardan bilgim yeterli diyenlerin \%6,7'sine, bilgim yetersiz diyenlerin \%0,3'üne göre Türkiye'de organ bağışı oranları yeterliydi ve gruplar arasındaki fark istatistiksel olarak anlamlıyd $\left(X^{2}=28,899 ; \mathrm{p}<0,05\right)$ (Tablo 5).

Tablo 5. Katılımcıların organ bağıısı konusunda bilgi düzeyine göre bazı tutum ve davranışlar.

\begin{tabular}{|c|c|c|c|c|c|c|c|c|}
\hline \multirow{2}{*}{$\begin{array}{l}\text { Organ bağışı konusunda } \\
\text { bilgi düzeyine göre bazı } \\
\text { tutum ve davranışlar }\end{array}$} & \multicolumn{2}{|c|}{$\begin{array}{l}\text { Bilgim yeterli } \\
(\mathrm{n}=298)\end{array}$} & \multicolumn{2}{|c|}{$\begin{array}{l}\text { Bilgim yetersiz } \\
(\mathbf{n}=\mathbf{3 4 3})\end{array}$} & \multicolumn{2}{|c|}{$\begin{array}{l}\text { Toplam } \\
(\mathrm{n}=641)\end{array}$} & \multirow[t]{2}{*}{$\mathbf{X}^{2}$} & \multirow[t]{2}{*}{$\mathbf{p}$} \\
\hline & Sayı & $\%$ & Sayı & $\%$ & Sayı & $\%$ & & \\
\hline Dini açıdan doğrudur & 172 & 57,7 & 152 & 44,3 & 324 & 50,5 & 11,896 & 0,003 \\
\hline $\begin{array}{l}\text { Tanımadığıma organ } \\
\text { vermem }\end{array}$ & 46 & 13,4 & 109 & 31,8 & 168 & 26,2 & 18,785 & 0,000 \\
\hline $\begin{array}{l}\text { Türkiye'de bağış oranları } \\
\text { yeterli }\end{array}$ & 21 & 6,7 & 1 & 0,3 & 21 & 3,3 & 28,899 & 0,000 \\
\hline
\end{tabular}

Organ bağışı yapan kişilerin tamamı (12 kişi) konu hakkında yeterli bilgim var diyen kişilerdi ve bilgim yetersiz diyenlere göre bağış yapma durumları anlamlı olarak yüksekti $\left(X^{2}=14,076 ; p=0,001\right)$.

Dini açıdan organ bağışının uygun olduğunu düşünenlerde organ bağışlama oranı daha yüksekti $\left(X^{2}=13,544 ; p=0,001\right)$.

\section{Tartışma}

Organ bekleyen hastaların sayısının her geçen gün arttığı ülkemizde toplumun organ nakli konusunda bilinçlenmesini sağlamak, bu konuda çalışmalar yapmak zorunlu hale gelmiştir [5]. Sağlık çalışanları, hastalar ve onların yakınları ile olan iletişimlerinden dolayı organ bağışının artırılması çalışmalarında anahtar rol oynarlar $[5,6]$.

$\mathrm{Bu}$ araştırmada hemşirelerin \%98,1'i organ bağışında bulunmamıştı. Şıpkın ve ark.'nın [7] 2008 yılında yaptı̆̆ bir çalışmada çalışmaya katılan öğretim elemanlarında organ bağışında bulunmayanların oranı \% 86,6 'dır. Bu çalışmada organ bağışı yapmayanların düzeyindeki yükseklik hemşirelerin konu hakkındaki farkındalıklarının yetersizliğinden veya kendilerinde ya da yakınlarından birinde organ nakline ihtiyaç duyulmamış 
olmasından kaynaklanan farkındalık eksikliği nedeniyle olabilir.

Hemşirelerin \%53,5'i organ bağışı konusunda yeterli bilgisi olmadığını ifade etti. Efil ve ark.'nın [8] yaptığı çalışmada katılımcıların \%51'i organ bă̆ışı konusunda yetersiz bilgiye sahip olduğunu, Akış ve ark.'nın [9] yapmış olduğu çalışmada çalışmaya katılanların \%72'si doku ve organ nakli konusunda bilgi sahibi olduğunu ifade etmiştir. Her iki çalışmada da bilgi düzeyi ölçümü yapılmamış ve kişilerin beyanına göre yeterli veya yetersiz değerlendirilmesi geçerli sayılmıştır. Bu çalışmanın bulguları Efil ve ark.'nın yaptığg çalışmanın bulgularıyla benzer, Akış ve ark.'nın yaptığı çalışmanın bulgularından ise düşüktür.

Hemşirelerin \%1,9'u organ bağışı yaptığını ifade etti. Tarhan ve ark.'nın [10] hasta yakınları üzerinde yaptığı çalışmada çalışmaya katılan hasta yakınlarının organ bağışında bulunma \%18,7; Saleem ve ark.'nın [11] Pakistan'da 408 katılımcı ile yaptıkları bir çalışmada organ bağışlama oranı \%3,5; Beutel ve ark.'nın [12] Almanya'da 1002 katılımcı ile yaptıkları çalışmada ise bu oran \%20 olarak bulunmuştur. $\mathrm{Bu}$ durum hemşirelerin organ bağışı konusunda yeterli bilgiye sahip olmamalarından, giderilmemiş tereddütlerden veya dini inanışlardan kaynaklanıyor olabilir.

Hemşireler organ bağışı konusundaki bilgilenme kaynaklarının başında interneti $(\% 43,1)$ belirtti. Şıpkın ve ark.'nın [7] yapmış olduğu çalışmada, çalışmaya katılanların \%93,9'u organ bağışı hakkında bilgisinin bulunduğunu, \%32,9'unun da bu bilgiyi gazete ve dergiden, Kavurmacı ve ark.'nın [13] yaptığı çalışmada ise \%46,6's1 televizyondan edindiklerini ifade etmişlerdir. Bu durum teknolojinin gelişmesiyle birlikte gazete alma ve okuma alışkanlığını şekil değiştirmesi, gazete ve dergilere de internet aracılığıyla ulaşılabilmesi ve internetin de sağlık kuruluşlarında var olması şeklinde açıklanabilir.

Grubun \%99,2'sine göre organ bă̆ışı yasald1, \%50,5'ine göre dinen sakıncası yoktu. Acar'a göre; kitap ve sünnetin ortaya koyduğu temel prensiplerle müctehidler tarafindan bunlara dayanılarak çıkarılan genel hükümler ve kaideler, tedavinin bir parçası olan organ naklinin caiz olduğunu söylemektedir. Organ bağışını dolayısıyla buna bağlı olarak organ naklini engelleyici olumsuz bir durum söz konusu değildir [4]. Hatta Diyanet İşleri Başkanlığı Din İşleri Yüksek Kurulu, organ bağışını insanın insana yapabileceği en büyük yardım olarak tanımlamıştır [14]. Efil ve ark.'nın [8] yaptığı çalışmada çalışmaya katılanların \%58,5'i dini inançların organ bağışına engel olmadığını, Aytaş Ö ve ark.'nın [15] yaptığ etmiştir. Şıpkın ve ark'nın [7] çalışmasına göre öğretim elemanlarından \% 85.4'ü dini yönden organ bağışını uygun bulmaktadır. Bu çalışmanın bulguları Efil ve ark.'nın yaptığı çalışma bulgularına benzer, Şıpkın ve ark'nın yaptığg çalışmanın bulgularından ise düşük bulunmuştur.

Hemşirelerin \%88,8'i aileden birine organ gerekirse, \%18,4'i hasta olan kişi bir yabanc1 ise organlarını verebileceğini belirtti. Özer Gök ve ark.'nın [16] üniversite öğrencilerinde yapmış olduğu çalışmada aileden birine organ gerekli olsa bağışta bulunmak isteyenlerin oranı \%96,2'dir. Bu çalışmanın bulguları Özer Gök ve ark.'nın yaptığı çalışmanın bulgularına benzer bulunmuştur. Aileden birinde organ ihtiyacı olması halinde bireyin hastalığından dolayı yaşadığ 1 sıkıntılara ve yaşam kısıtlılıklarına daha yakından tanık olunması organ gerektiğinde yabancı birine göre aileden birine verme isteğini artırıor olabilir.

Türkiye'de organ bağışının yetersiz olduğunu düşünen hemşireler $\% 74,1$ düzeyinde idi. Şıpkın ve ark.'nın [7] çalışmasındaki öğretim üyelerinin \%97,6'si ülkemizde yeterince organ bağış1 yapılmamakta olduğunu düşünmektedir. Bu çalışmanın bulguları Şıpkın ve ark.'nın yaptığı çalışmanın bulgularından düşük bulunmuştur. Bu durum hemşirelerin konunun önemi hakkında öğretim görevlilerine kıyasla daha az farkında olmalarından kaynaklanıyor olabilir. 
Organ bağışı ücretsiz sunulan bir hizmettir. Ancak Hemşirelerin \%2,3’ü organ bağışının ücretli bir işlem olduğunu düşünmekteydi. Koçak ve ark.'nın [17] tıp fakültesi öğrencilerinde yaptığı çalışmada da organ naklinin mali boyutu hakkındaki düşüncelerini çalışmaya katılanların \%45,6'sı "pahalı" olarak nitelendirmiştir. Operasyon maliyetinin yüksek olması, işlemin ücretli olduğunu düşündürüyor olabilir.

Bağışı mümkün olan organlar sorulduğunda en fazla ifade edilen organ böbrek $(\% 98,1)$ idi. Vicdan ve ark.'nın [18] yaptığı çalışmada hangi organlar bağışlanabilir sorusuna çalışmaya katılanların \%95,9'u böbrek cevabını vermiştir. Bu çalışmanın bulguları Vicdan ve ark.'nın yaptığı çalışmanın bulgularına benzer bulunmuştur. Bu da en çok gündeme gelen ve duyulan nakillerin böbrek olmasından kaynaklanıyor olabilir.

Kişiler öldükten sonra onların adına organ bağışı kararını birinci derece yakınlarının vereceğini düşünen hemşireler \%88,0'l1k bir grubu oluşturmaktadır. Kişi ölmeden önce resmi olarak organ bağışında bulunmamış ise fakat yaşarken bu konu hakkında olumlu veya olumsuz fikrini ailesine belirtmiş olabilmeleri ihtimalinin yüksekliğinden dolayı; ölmüş kişi adına kararı yakınlarının vereceğini düşünüyor olabilirler.

Organ bağışının artırılması için önerileri sorulduğunda hemşireler, eğitimlerin artırılmasını $(\% 93,3)$, din görevlilerinden yardım alınmasını $(\% 75,2)$ dile getirmişlerdir. $\mathrm{Bu}$ eğitimler ve din görevlilerinden alınacak yardım sayesinde organ bağışı hakkında bilgi eksiklikleri giderilirken; aynı zamanda dinen yasak olmadığının din görevlileri tarafından bizzat halka iletilmesiyle konu hakkındaki farkındalık artışı ile organ bağışının arttırılabileceğini düşünmüş olabilirler.

$\mathrm{Bu}$ araştırmada organ bağışı yapan hemşirelerin tamamı (12 kişi) "konu hakkında yeterli bilgim var" diyen kişilerdi ve "bilgim yetersiz" diyenlere göre bağış yapma durumları anlamlı olarak yüksekti. Dini açıdan da organ bağışının uygun olduğunu düşünenlerde organ bağışlama oranı daha yüksekti. Organ nakli konusunda bilgi düzeyi arttıkça organ bağışlama oranının artması, bu konudaki farkındalık ve bilgi seviyesinin yükselmesi, varolan dini tereddütlerin giderilmesi sağlanırsa olumlu tutum kazanılacağı ve organ naklinin artırılması konusunda davranışa yönelik somut adımlar atılacağı yönünde umut verici olarak değerlendirilebilir. Sağlık profesyoneli olmaları nedeniyle kendilerine gelecek sorulara da yanıt verecek bir grup olarak daha bilgili ve hassas olmaları beklenen bu gruptaki bilgi eksikliklerinin giderilmesi hizmet içi eğitimlerle mümkün olabilir.

\section{Kaynaklar}

1. Organ ve Doku Nakli Hizmetleri Yönetmeliği, 25748 sayılı resmi gazete, 07.03.2005.

2. Özdağ N. Organ nakli ve bağışına toplumun bakışı. CÜ. Hemşirelik Yüksekokulu Dergisi 2001; 5: 46-55.

3. Göz F, Gürelli ŞŞ. Yoğun bakım hemşirelerinin organ bağışı ile ilgili düşünceleri. Fırat Sağl1k Hizmetleri Dergisi 2007; 2: 77-88.

4. Acar İ. Organ bağışının dinimizdeki yeri. Atatürk Üniversitesi İlâhiyat Fakültesi Dergisi 2007; 27: 17-30.

5. Göz F, Şalk Gürelli Ş. Yoğun bakım hemşirelerinin organ bağışı ile ilgili düşünceleri. Furat Sağlık Hizmetleri Dergisi 2007; 2: 77-88.

6. Tamburi LM. "The Role Of Critical Care Curses in The Organ Donation Breakthrough Collaboratıve", Critical Care Nurse 2006; 26: 20-2.

7. Şıpkın S, Şen B, Akan S, Tuna Malak A. Onsekiz Mart Üniversitesi Tip Fakültesi, İlahiyat Fakültesi ve Güzel Sanatlar Fakültesi öğretim elemanlarının organ bağışına bakış açılarının incelenmesi. ADÜ Tıp Fakültesi Dergisi 2010; 11 : 19-25.

8. Efil S, Şişe Ş, Üzel H, Eser O. Afyon İlinde Halkın ve Afyon Kocatepe Üniversitesi Tıp Fakültesi sağlık çalışanlarının organ bağışı konusuna ilgilerinin değerlendirilmesi. Gümüşhane Üniversitesi Sağlık Bilimleri Dergisi 2013; 2 36184. 
9. Akış M, Katırcı E, Uludağ H, Küçükkılıç B, Gürbüz T, Türker Y, Kayacan H, Öngel K, Gül H. Süleyman Demirel Üniversitesi personelinin organ-doku bağış1 ve nakli hakkındaki bilgi ve tutumları. SDÜ Tıp Fakültesi Dergisi 2008; 15: 2833.

10. Tarhan M, Dalar L, Yıldırımoğlu H, Sayar A, Altın S. Hasta yakınlarının organ bağışı ve nakli ile ilgili tutumları ve sosyal profilleri arasındaki ilişki. Bakırköy T1p Dergisi 2013; 9: 152-8.

11. Saleem T, Ishaque S, Habib N. Knowledge, attitudes and practices survey on organ donation among a selected adult population of Pakistan. BMC Med Ethics 2009; 10: 5.

12. Beutel ME, Greif-Higer G, Haselbacher A, Galle PR, Otto G. Attitudes towards cadaveric organ donation results from a presentative survey of the German population. Z Gastroenterol 2006; 11: 1135-40.

13. Kavurmac1 M, Karabulut N, Koç A. Üniversite öğrencilerinin organ bağış1 hakkındaki bilgi ve görüşleri. Hemşirelikte Eğitim ve Araştırma Dergisi 2014; 11: $15-21$.

14. Göz F, Şalk GŞ. Yoğun bakım hemşirelerinin organ bağışı ile ilgili düşünceleri. Firat Sağl1k Hizmetleri Dergisi 2007; 2: 77-88.

15. Aytaş Ö, Kartalcı Ş, Ünal S. Bir grup hemşirenin sosyodemografik verileri ve tükenmişlik düzeyleri bağlamında organ bağışına bakış açıları. İnönü Üniversitesi Tip Fakültesi Dergisi 2011; 18: 26-32.

16. Özer Gök F, Yavuz A, Beydağı KD, Fidancıoğlu H, Akın E, Sanlı I, Tembela H, Bozkurt L, Urak S. Pamukkale Üniversitesi Denizli Yüksek Okulu'nda öğrenim gören bir grup öğrencinin organ nakli ve bakışına yönelik görüşleri ve bilgi düzeylerine eğitimin etkisi. TSK Koruyucu Hekimlik Bülteni 2008; 7: 39-46.

17. Koçak A, Aktaş E Ö, Şenol E, Kaya A, Bilgin U E. Ege Üniversitesi Tıp Fakültesi öğrencilerinin organ nakli ve bağışı hakkındaki bilgi düzeyi. Ege Tıp Dergisi 2010; 49: 153-60.

18. Vicdan Kacaroğlu A, Peker S, Üçer B. Akşehir Sağlık Yüksekokulu öğrencilerinin organ bağışı ile ilgili tutumlarının belirlenmesi. TAF Prev Med Bull 2011; 10: 175-80. 